This item was submitted to Loughborough's Research Repository by the author.

Items in Figshare are protected by copyright, with all rights reserved, unless otherwise indicated.

\title{
Configuring management control systems: theorizing the integration of strategy and sustainability
}

PLEASE CITE THE PUBLISHED VERSION

http://dx.doi.org/10.1016/j.mar.2012.06.003

PUBLISHER

(C) Elsevier Ltd.

VERSION

AM (Accepted Manuscript)

LICENCE

CC BY-NC-ND 4.0

\section{REPOSITORY RECORD}

Gond, Jean-Pascal, Suzana Grubnic, Christian Herzig, and Jeremy Moon. 2019. "Configuring Management Control Systems: Theorizing the Integration of Strategy and Sustainability". figshare.

https://hdl.handle.net/2134/14654. 
This item was submitted to Loughborough's Institutional Repository (https://dspace.lboro.ac.uk/) by the author and is made available under the following Creative Commons Licence conditions.

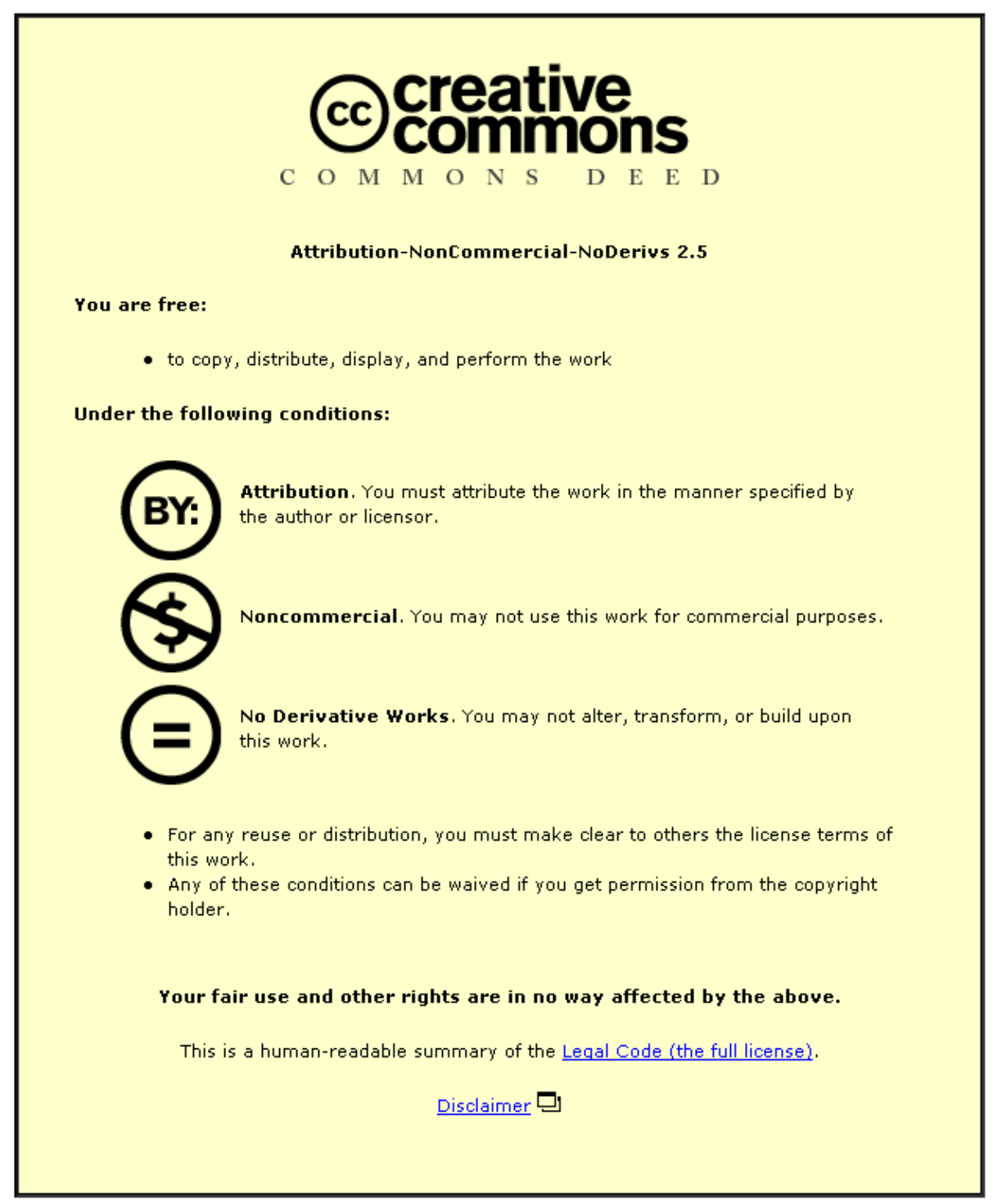

For the full text of this licence, please go to: http://creativecommons.org/licenses/by-nc-nd/2.5/ 


\title{
Configuring Management Control Systems: \\ Theorising the Integration of Strategy and Sustainability
}

\begin{abstract}
Although organizations have embraced the sustainability rhetoric in their discourse and external reporting, little is known about the processes whereby management control system contributes to a deeper integration of sustainability within organizational strategy. This paper addresses this gap and mobilizes a configuration approach to theorise the roles and uses of management control system (MCS) and sustainability control system (SCS) in the integration of sustainability within organizational strategy. Building on the levers of control framework, we distinguish two possible uses of a MCS and a SCS - a diagnostic use and an interactive use-, and we specify the modes of MCS and SCS integration. We rely on these two core dimensions to identify eight organizational configurations that reflect the various uses as well as their modes of integration of SCS and MCS. We characterize these ideals-type configurations, explain their impact on the triple bottom line, and describe which mechanisms allow organizations to move from one configuration to another. In so doing, we highlight various paths toward sustainability integration or marginalization within organizations. Finally, we explain how our framework can support future research on the role of MCS and SCS in the integration of sustainability within strategy.
\end{abstract}

Key words: Management Control Systems/MCS, Levers of Control, Use and Integration of MCS, Sustainability Accounting, Strategic Management Accounting 


\section{Configuring Management Control Systems: Theorising the Integration of Strategy and Sustainability}

\section{Introduction}

Awareness of the role of human agency in climate change has reached a climax in the business world and a consensus emerges on the idea that 'there is no alternative to sustainable development' [1]. Sustainability involves organizational strategic renewal [2,3] as well as the creation of new calculative practices which drive, for example, the development of carbon trading markets $[4,5])$ and sustainability accounting and reporting $[6,7,8]$. This has led to the emergence of alternative paradigms to the financial profit maximisation captured in such phrases as the 'triple bottom line' in which economic, social and ecological criteria of performance are expected to be integrated [9].

Although organizations have embraced the sustainability rhetoric in their external reporting and their mission statements [10], research suggests these reports may serve as 'veils' hiding activities from scrutiny [11] whose sole purpose is the reconstruction of an eroded legitimacy $[12,13]$. This sceptical view is nurtured, on the one hand, by a lack of study of the intraorganizational impact of sustainability [14], and, on the other hand, by the scant attention devoted to the role of management control systems supporting sustainability within organizations [15]. It is finally enhanced by anxieties concerning the capacity of any strategic move toward sustainability to alter organizational practices [16].

However, because management control systems (MCSs) shape actors' practices $[17,18]$ and support strategy $[19,20]$, they can contribute to push organizations in the direction of sustainability. MCSs are central to strategy-making, as they shape the process of strategy 
emergence and support the implementation of deliberate strategies [21,22,23,24,25,26,27,28]. Accordingly, lasting attempts to integrate sustainability within strategy, beyond external reporting, discourse and mission statements, should be reflected at some stage within formal control mechanisms [29].

Although sustainability has been discussed in the management control literature to describe the emergence of sustainability control systems (hereafter SCSs) such as eco-control, this stream of research is mainly focused on the influence of these systems on environmental and financial performance [30,31]. Little is known about the nature and mode of integration between SCSs and more traditional MCSs [32]. Yet, SCSs can contribute to an effective integration of sustainability within strategy only when they inform MCSs and are not used as 'autonomous strategic tools' [33,34]. Short of this, SCSs may remain peripheral and decoupled to core business activities and fail to reshape strategy. We will illustrate these “parallel worlds of MCSs and SCSs” in more detail below (Table 1).

The aim of this paper is theorize further the roles and uses of MCSs and SCSs in the integration of sustainability within strategy. We seek to theorize the neglected relationships between MCSs and SCSs, as well as their co-influence in the process of organizational strategy development. Our aim is to clarify how MCSs and SCSs are related, and how together, and in relation with strategy-making, these systems can prevent or facilitate the emergence of sustainability at strategic level and ultimately the integration of sustainability and strategy.

Central to our argument are two concepts: the integration and the use of MCSs and SCSs. We define in this paper integration as the degree of overlap between the two types of control 
systems under study and approach integration as a thick socio-technical process [35] which includes technical/methodological [36], social [37,38,39] and cognitive [40,41] components. Our concept of uses of management control systems is derived from Simons' levers of control framework [42,43,44,45,46,47]. More specifically, we distinguish control systems used by executives as 'management by expectations' tools (diagnostic) to correct actors' actions, from control systems used as 'actual strategic levers' (interactive) to focus actors’ attention on key goals and support changes aligned with higher strategic objectives.

We explore the combinations of modes of integration and diagnostic vs. interactive uses of control systems to delineate a parsimonious number of plausible configurations of SCSs and MCSs within organizations. We approach these configurations as ideal-types, in the Weberian sense of the term, that is "the one-sided accentuation of one or more points of view and by the synthesis of a great many diverse, more or less present and occasionally absent concrete individual phenomena” [48]. We theorize the relationship between these ideal-types and organizations' capacity to elaborate a sustainability strategy. In line with prior configuration theory-building $[49,50]$, we specify our framework by explaining which moves between configurations can support a change in strategic orientation toward sustainability. Finally, we discuss how this framework can support further empirical studies on the role of formal control systems in the integration of sustainability within organizational strategy.

The paper is organized as follows. Part 2 describes the role of MCSs for strategy-making and reviews prior developments in sustainability control and strategy. Part 3 specifies the various modes of integration of management and sustainability control systems as well as their various uses. Part 4 explores the various configurations of both regular MCSs and SCSs and explains how they relate to specific approaches to sustainability strategy. Part 5 theorizes 
how moves across configurations explain the integration of sustainability within organizational strategy. Part 6 discusses the implications of the framework for future research on the role of management accountants and management control for promoting practices on sustainability.

\section{Management Control Systems, Strategy and Sustainability}

\subsection{Management Control as Strategy-Making}

In a deviation from prior literature on management control systems and strategy, Simons (1991) conveys the idea of formal control systems influencing strategic processes within organizations. Up until this point, the approach taken by researchers was to view control systems as passively following change and not, in a direct contrast, as control systems proactively shaping change [51]. Simons [52] highlights the role of information-based routines and procedures in both elucidating strategic uncertainties and revealing strategic risks. Accordingly, formal controls have a role in strategic renewal in the minimization of organizational threats and in the embracing of opportunities arising from competitive dynamics or internal competencies. In recent works, Simons (2006) applies strategic renewal at different stages in a firm's business life-cycle and by newly appointed managers seeking to promote agendas.

In reviewing the literature on MCSs and strategy, Langfield-Smith [53] observes the use of single constructs of strategy in research studies and points to dangers in an underlying assumption that managers view their organization's strategy in the same terms. More specifically, Langfield-Smith argues that strategy is multi-dimensional in nature but that this is rarely recognized by researchers in published studies. Following on, she points to problems in under-specifying strategy and implies care be taken in research design in order to uphold 
the integrity of research findings. In a similar vein, Chenhall [54] argues that strategy constructs used in accounting studies may be outdated. Following on, strategy in case-based studies need not be confined, for example, to typology (prospector, analyzer, defender), mission (build, hold, harvest) and competitive position (cost leadership and differentiation). Further, Langfield-Smith [55] makes the point that strategy is under continual construction or, in her terms, "an ongoing developmental process". Her study paves the way for alternative conceptions of strategy particularly that strategy is dynamic in nature.

Consistent with Simons' study [56], the present paper views formal control as predominantly contributing to either strategy formulation or to strategy implementation. Use of formal control is predominantly for the development of emergent strategies or else for the realization of intended strategies. In terms of the former, interactive control systems involve dialogue between top managers and subordinates in an effort to stimulate organizational learning and the development of new strategic initiatives. The link between interactive control and strategy-making is re-inforced in the finding of Widener [57] that interactive control is used to scan the external environment and, by implication, feed into strategic positioning. In relation to the latter, diagnostic controls are used by executives as 'management by exception' tools in order to correct actors' actions and align activities toward the achievement of critical success factors. Interactive and diagnostic controls are considered exclusively in the works of Abernethy and Brownell [58]; Bisbe and Otley [59]; Henri [60]; and Kober et al. [61].

Focus upon two levers of control from Simons' [62] Levers of Control (LOC) framework should not be interpreted as the neglect of the other two levers. Interactive and diagnostic controls are used in order to identify configurations of control systems and, in so doing, theorize on an organization's capacity to integrate sustainability into strategy. As depicted 
diagrammatically by Simons $[63,64]$, belief and boundary systems surround the use of interactive and diagnostic controls and therefore cannot be considered as separate to them. Empirical support is provided by Widener [65] that belief systems do indeed influence each of the other three systems. Further, Simons [66] suggests bi-directional relations between interactive and belief systems on the one hand and boundary and diagnostic systems on the other. The pairs are theoretically plausible given that interactive-belief systems serve to empower organizational actors and boundary-diagnostic systems seek to constrain and ensure compliance with rules. On a practical level, belief and boundary controls are less amenable to systematic investigation but, nevertheless, can be used to elaborate on and interpret findings.

In a brief review of the approaches taken by researchers in the operationalization of the LOC framework, Mundy [67] observes differences in choices made in the selection of MCSs. For the purpose of this study, and consistent with Mundy, a 'package' of MCSs used by directors in forming and supporting strategy is incorporated. To this end, the selection of specific MCSs has been guided by a variety of works.

Following the lead of Simons [68,69], firstly, the MCSs are confined to accounting controls. Examples of systems other than accounting include human resource systems, career planning systems and intelligence systems to name a few [70]. The decision not to expand controls is for theoretical and pragmatic reasons: to examine relationships with sustainability control systems and maintain tractability [71]. Secondly, the MCSs included in our 'package', as far as possible, are relevant to contemporary organizations. We note, for example, the argument of Nixon and Burns [72] that there is a gap between the extant management control literature and practice as well as between the concepts in management control literature and conceptual developments in strategic management. Controls presented in prior literature (see Berry et al. 
[73] for a recent review of literature on management control) have been adjusted to have general applicability to national and multinational organizations operating in a competitive environment. Finally, for purposes of completeness on cybernetic controls, the MCSs encompass controls on the same presented by Malmi and Brown [74] in their normative conceptual framework of management controls. The framework by the authors is based on extensive research covering a forty-year period, and includes the works of Chenhall [75]; Fisher [76,77]; Flamholtz et al. [78]; Langfield-Smith [79]; Otley [80]; and, Simons [81]. This study, in deviation from Malmi and Brown [82], does not explicitly include informal controls such as occurs in the socialization of organizational members through training or the practice of clan controls [83].

Formal controls, as presented in columns 1 and 2 of Table 1, comprise: strategic planning; budgeting; financial measurement systems; non-financial measurement systems; hybrid measurement systems; project management; and, evaluation and reward. The inclusion of three performance measurement systems corresponds with Simons [84] shift towards performance measurement (as reflected in the title of his 2006 text) as well as remarks by Langfield-Smith [85] and Widener [86] that performance measures are necessary regardless of strategy pursued. According to the management control literature, budget systems (e.g., Abernethy \& Brownell [87]; Bisbe \& Otley [88]; Kober et al. [89]), non-financial measures (e.g., Vaivo [90]), hybrid measurement systems such as balanced scorecards or tableaux-debord (e.g., Bisbe \& Otley [91]; Henri [92]; Marginson [93]; Tuomela [94]), and project management (e.g., Bisbe \& Otley [95]; Davila [96]) have been used interactively as well as diagnostically within organizations. The MCSs included have been shown to contribute to strategy-making (through non-specific packages of organizational controls) through 
deployment of interactive controls in the studies of Bruining et al. [97]; Widener [98]; Mundy [99].

INSERT TABLE 1 ABOUT HERE

In the next section, issues of integration in relation to sustainability, regular MCSs and strategy are discussed.

\subsection{Sustainability Management Control and Strategy}

The MCSs described above were traditionally developed to align organizational and behavioural structures with the economic goals of organizations and to assist in improving economic performance. Despite more recent developments in hybrid and non-financial measurement systems and research indicating that financial and non-financial information can be considered equally important for both strategy deployment and development [100], these traditional MCSs are seen to be limited in incorporating the interests of a broad range of stakeholders other than shareholders and in addressing environmental and social issues as well as their inter-relationships with financial issues [101,102,103,104]. As a response to these limitations and to the prevalence of contemporary sustainability issues such as climate change, various internal sustainability accounting systems and techniques have been developed and implemented by organizations. Column 3 of Table 1 provides an overview of some specific sustainability approaches to management accounting and control. They are mainly derived from the large body of literature on environmental management accounting and eco-control that has burgeoned in the last two decades and, more recently, has started to capture the broader aspects of sustainability - see summaries of previous work in Lamberton [105], Thomson [106], and Burritt and Schaltegger [107]. Within this research stream, attention has often been paid to the development and of individual systems and tools of environmental/sustainability management accounting and control (such as environmental 
budgeting, environmental/sustainability performance evaluation systems, eco-control or sustainability balanced scorecard). In contrast, little research has investigated the interplay of these systems with regular management control, the improvements in decision-making created through better integration and how to overcome organizational barriers preventing such integration $[108,109]$. With the exception of a very few in-depth case studies that have recently examined the relationships between MCSs in the context of socially responsible managerial decision-making $[110,111]$ empirical evidence is scarce yet and our understanding of the interaction among these new forms of SCSs and their relationship with regular MCSs is limited. Some have thus called for more research into the needs and the specific decision situations of the company managers as well as the use of various systems and tools when making environmental or sustainability related decisions [112]. Similarly, others have stressed that the implementation process and related questions that arise from the use of management accounting tools and systems in the context of sustainability (such as integration-oriented cooperation and boundary-crossing, organisational learning) requires more attention $[113,114]$. In illuminating the various organizational processes whereby sustainability accounting contributes to raise awareness about and facilitates communication on sustainability issues inside organizations, we aim to contribute to advancing the disciplines of sustainability management accounting and providing impetus for future research.

Likewise, it appears that the current evolution of the field of sustainability in strategic management [115] would benefit from a broader perspective that also looks at the relationships and interactions between MCSs and SCSs. As discussed in the previous section, MCSs are seen to play a critical role in influencing the process of strategy-making throughout the organization and thereby guiding organisational learning. Embedding stakeholders' expectations and sustainability issues within the strategy thus calls for a closer look at the 
interplay between these two kinds of systems and how organizational moves towards more sustainability can be enhanced by mobilizing simultaneously and strategically these two systems. Drawing on Milne [116] we argue that approaching the field of sustainable strategic management from this process perspective increases the understanding of the power of management accounting systems in meeting the increasing complexity of present global problems and contributing to the sustainability strategy formulation process. Our research reflects the fact that our understanding of managers' key arguments or business logic for adopting sustainability strategies is still insufficient [117]. We propose that better understanding of the links between the two kinds of systems and their contribution to making a genuine sustainability strategy could enable organizations to move away from sustainability accounting systems operated in parallel to the 'regular' management control and often built in response to external legal and societal pressures [118] to more integrated and dynamic uses of control systems which support the development of new business opportunities.

\section{Dimensions of Sustainability Integration in Strategy}

\subsection{Integration of Control Systems}

In this paper, we approach integration as a thick socio-technical process [119] and distinguish three dimensions of integration: technical, organizational and cognitive.

Technical Integration: Technical Integration refers to the necessity of considering single practices of sustainability control within a broader system of management control. It is defined here as the integration of regular MCSs with activities and systems that can be described as internal sustainability management control but are dealt with outside the management control function of organizations. Despite the presentation of two parallel worlds, the descriptions of MCSs and SCSs (Table 1) reveal potential for methodological 
integration. However, in practice, these accounting systems, developed and used for managing and reporting sustainability impacts, vary in the way they are integrated into 'regular' MCSs [120]. When SCSs are run in parallel to traditional MCSs in practice, there is the consequence of hampering organizational decision-making drawing on the broadest possible foundation of economic, ecological and social data that is available in the organization [121]. Therefore, technical integration involves methodological links between the two encompassing types of systems, such as the presence of a common calculability infrastructure to gather information for both systems.

Organizational Integration: Rather than seeing regular and sustainability management control just as something organizations have, we argue that integrating sustainability in management control and strategy should also be approached as something people $d o$, in line with recent calls for a practice perspective in management control and strategy [122,123,124,125,126]. By defining actors' roles and organizations' formal structure in ways that facilitate the socialization of management accountants to specialists of sustainability reporting and control, organizations can reach a form of systemic integration, even though systems technically remain separated. We therefore argue that integration should also be approached through the ‘social practice’ lens. Organizational integration can be reached through groups which may have developed similar practices of reporting or management control, although they do not belong to the same part of the organizational structure and do not operate through the same systems. This ‘community of practice’ [127] can be made of accountants and managers using both or different systems yet sharing a set of common practices [128].

Cognitive Integration: Finally, regular and sustainability control systems can also be viewed as communication platforms that facilitate interaction and create opportunities for discussion 
between people who bring with them different patterns of thinking, mindsets and practical viewpoints with regard to sustainability. The main aim of such dialogue is to attempt an exchange of knowledge between those involved, to reach an understanding and to overcome or redefine cognitive boundaries. Cognitive dimensions of integration have been deemed as crucial for sustainability integration within organizations in prior works $[129,130]$. Therefore, we argue, a complete overlap of both management control and sustainability systems should also be reflected in shared cognitions among the managers working on mainstream strategy/control and sustainability. Crucial to overcoming cognitive biases that are socially and environmentally dysfunctional and that perpetuate unsustainable practices [131] is the process of working towards a common frame of reference or a shared perception of reality [132]. Even if the adoption of sustainability and its integration into management control is viewed as necessary, this is easier said than done. An expansion of perspectives requires knowledge that is exchanged and assimilated into the respective individuals' own knowledge structures.

In identifying the different dimensions of sustainability integration into strategy through management control system we consider an overall level of systems integration. This overall integration is a continuum variable that reflects the aggregated level of technical, organizational, and cognitive integration. We also assume that overall integration can be either high or low. In organizational contexts characterized by high levels of integration, both systems are tightly coupled whereas they are only loosely coupled in low integration contexts. We use this broad approach to integration to shed light on the relationship between the two encompassing types of systems (traditional MCSs and SCSs) and to complement Simons' perception on the use of MCSs for strategic decision-making, as described in the next section. 


\subsection{Strategic Uses of Management Control Systems}

As discussed in section 2.1, Simons distinguishes between interactive and diagnostic control systems on the basis of contributions to the strategy-making process. Diagnostic control systems are tools that help in the achievement of an organization's intended strategies. By contrast, interactive control systems provide input into the formation of strategy. That is to say, interactive control systems stimulate and guide emergent strategies in response to opportunities and/or threats within an organization’s operating environment.

Diagnostic control systems: These systems introduce ex post monitoring and are utilized with the intention of transforming intended strategies into realized strategies. Diagnostic control systems involve (i) setting standards; (ii) measuring process outputs in relation to pre-set standards; and, (iii) taking action when there is a deviation between pre-set standards and actual results. Senior managers are involved on an exceptional basis only, or in the review of key measures and critical success factors when setting standards.

Interactive control systems: The purpose of such systems is to direct managers' attention toward strategic uncertainties and to learning novel strategic responses to a changing environment. Interactive control is practised when (i) information generated by the MCS is an important and recurring agenda addressed by top management; (ii) the process demands frequent and regular attention from managers at all levels; (iii) data are discussed and interpreted in fact-to-face meetings among organizational members of different hierarchical levels; and, (iv) the process relies on the continual challenge and debate of underlying data, assumptions, and action plans (Simons [133]). Given the need for significant amounts of top management attention, Simons [134] finds that managers limit interactive systems to one system only. 
Building upon the two concepts of use and integration of control systems, the next section describes different configurations of MCSs and SCSs.

\section{Defining Configurations of Control Systems}

In order to appreciate the modes of sustainability integration within corporate strategy, we rely on the various uses of both sustainability and management controls (diagnostic vs. interactive) as well as on their level of integration to delineate 'ideal-types' of organizational configurations. To do so, we distinguish two encompassing types of systems (management control vs. sustainability) and consider an overall level of systems' integration. Within these restrictive assumptions we delineate eight organizational configurations relating to integration of MCSs and SCSs and to their specific uses. These eight configurations are summarized in Table 2 and discussed in-depth below.

We introduce these 'ideal-types’ by moving from systems’ diagnostic to interactive uses. We first introduce low levels of integration configurations (characterized by a loose coupling between MCSs and SCSs) and then configurations with high levels of integration (tight coupling of MCSs and SCSs). We discuss for each configuration the relationships between systems, provide an empirical illustration, and then specify some parameters of these configurations, such as their stability, their empirical verisimilitude and their capacity to enhance simultaneously the environmental, social and economic dimensions of the bottom line (impact on the 'triple bottom line').

INSERT TABLE 2 ABOUT HERE 


\subsection{Dormant decoupled strategy (Configuration A)}

A first ideal-type organizational configuration corresponds to a situation within which the organization possesses parallel systems of control for management and sustainability, yet none of them is actually mobilized to deploy any kind of strategy. As explained by Simons [135]: "when top managers of large business do not have a vision for the future-or a sense of urgency about creating such a vision-they do not appear to make control systems interactive”. In this context of 'dormant decoupled strategy', the organization lacks vision for future development in both the strategic and sustainability domains. This situation prevents the emergence of a clear strategy and thus the focus on a control system.

This situation can occur, for instance, for developed or bureaucratized organizations enjoying monopoly power in their market but whose power is declining due to the entry of new more dynamic competitors. In such organizations control systems for traditional management and sustainability may have grown progressively and independently and kept being used diagnostically. Some large formerly state-owned European utility and transport companies faced these challenges when the energy market was liberalized in Europe. The 'dormant decoupled strategy' configuration can occur in the less frequent contexts described by Meyer and Zucker [136] as “permanently failing organizations” within which actors fail to agree on a clear strategic direction and thus maintain uncertainties about the organization's future.

For corporations acting in dynamic and competitive markets or listed on the Stock Exchange, such a situation is likely to be transitory, as pressures for strategizing are likely to emerge either from shareholders or competitors. A persistent lack of strategy in a competitive environment would probably force the corporation out of business. We can therefore assume 
that, the empirical verisimilitude is low as this configuration's stability is low and confined to periods of strategy 'crisis' [137] -apart from the relatively exceptional case of "permanently failing organizations” [138]. The entrance of a new head or CEO may indeed stimulate the adoption of a new clear vision [139]. Organizations characterized by such a 'dormant decoupled strategy’ are unlikely to reconcile environmental, social and economic performance either in the short or in the long run.

\subsection{Strategy emergence through sustainability (Configuration B)}

A possible move from the 'dormant decoupled strategy' configuration consists in having a change in the use of the SCS. The move from a diagnostic to an interactive use of SCS can reflect an emerging strategic renewal through sustainability. In this case of 'emerging sustainability strategy', MCSs and SCSs are still not integrated, but the sustainability system is mobilized strategically by the top management team to deploy a sustainability strategy [140]. Hence, the strategy 'emerges' from the sustainability area within a dormant context [141].

Although such a configuration seems to be empirically less plausible, its existence can be explained, for instance, by the creation of a dynamic new department for sustainable development or CSR, made of entrepreneurial actors who are triggering changes within a bureaucratized or mature organization. These changes can be co-opted by top managers aiming at testing the ecological viability of this strategy within the organization [142] and thus using interactively this control system [143]. The emergence of this configuration can also be related to the willingness of a new top management team to promote strategic renewal through sustainability, by focusing managers' attention on this specific system [144]. Within such a configuration, it can be expected that organizations perform well on the non-financial 
dimensions but struggle to enhance their financial performance, resulting in a medium capacity to achieve a triple bottom line.

\subsection{Compliance driven sustainability strategy (Configuration C)}

A second possible move out of the dormant decoupled strategy refers to the situation within which an organization mobilizes one of its MCSs to deploy its strategy [145,146,147], yet pays little attention to sustainability issues which are managed diagnostically through a system that operates parallel to the dominant MCS. One case in point is the development of the sustainability control system driven by external pressures to report on social and environmental issues (e.g., legal pressures and/or stakeholder pressures) [148,149].

According to many observers of organizational life, this situation is often observed during early stages of sustainability integration [150,151,152]. For instance, at the early stages of the Nike case reported by Zadek: “the company realized it couldn't just shut out the noise. It eventually responded to activists' demands for labor codes and, after further pressure, agreed to external audits to verify whether these codes were being enforced” [153]. The Corporate Responsibility department of Nike emerged as an organizational answer to these external pressures [154]. With this 'compliance-driven sustainability strategy', the sustainability control system is usually used as a 'management by exception tool' to detect a 'big issue' and to report annually on sustainable performance.

The sustainability data produced by the organization can hardly feed into any internal management processes as there is a decoupled organizational context $[155,156]$. Thus, this configuration leaves little room for innovation and organizational learning through the use of the sustainability system $[157,158]$. In this regard, this configuration presents an important 
level of stability, except in contexts within which the organization is challenged by specific issues or broader social movements, as in the case of sweatshops with Nike. The sustainable discourse and practice run the risk of being externally perceived as 'greenwashing' or 'window dressing' [159, 160]. Accordingly, the organizational capacity to combine environmental, social and economic performance remains low at this stage, even though the organization may exhibit high levels of financial performance.

\subsection{Schizoid sustainability strategy (Configuration D)}

The fourth and last configuration exhibiting 'low-integration' refers to an organizational context within which contradictory sustainability and traditional strategies are followed and deployed through parallel sustainability and traditional MCSs. Although this 'schizoid sustainability strategy' is probably unusual, its existence finds theoretical and empirical grounds.

Theoretically, Kets de Vrie and Miller [161] argued that organizations are likely to experience ‘neurotic symptoms’ such as schizophrenia. Prior research suggests contradictory injunctions are not uncommon within organizational contexts [162], and these situations may trigger schizophrenic symptoms [163]. Accordingly, the deployment of control systems supporting contradictory logics can be a way to delegate to lower managerial echelons the management of tradeoffs and tensions which have not been effectively managed at the higher end of the organization. It could also reflect a disagreement at the board level about the levels of priority to grant to strategic uncertainties.

Other theoretical arguments explain the presence of a 'loosely coupled' but yet fully developed sustainability strategy. For instance, such a sustainability strategy is a stronger 
shield to buffer external pressures and external scrutiny through manipulation than superficial reporting exercises and to present a façade of conformity [164]. A 'realist' façade of conformity can be a way to attract institutional support for illegitimate actions [165], a case in point being the instrumentalization of CSR practices by Mafia organizations [166].

Empirically, diversified US-based multinational corporations have been shown to exhibit contrasted sustainable behaviours in various countries, supporting the view of corporate actors 'being good while being bad' [167]. Accordingly, this configuration could be of a medium frequency. Critical analyses of the corporations which are the most invested in by responsible investors also suggest that sustainability performance may vary heavily across their different impacts on stakeholders $[168,169]$. For instance, Microsoft is simultaneously praised for its social initiatives while having been found guilty of violations of the anti-trust legal framework [170]. In addition, a temporary lack of systems' coordination can also be a transitory situation faced by organization implementing an organizational change toward sustainability. This configuration is thus characterized by a low level of stability. Finally, in terms of triple bottom line performance, this configuration can generate high convergence between the various dimensions of performance in the short run, even though it does not enable this convergence to be sustained in the long run.

We now turn to the characterization of a second set of ideal-type configurations that correspond to situations where sustainability and regular MCSs are strongly coupled and integrated, through cognitive, organizational and/or technical processes (bottom line of Table 2). This 'high' integration means that SCSs and regular MCSs are coordinated. Yet, important differences emerge from the various uses of both systems in these contexts. 


\subsection{Dormant integrated strategy (Configuration E)}

Although, both systems can be strongly tied, they are not necessarily mobilized to deploy any kind of strategy. This situation of ‘dormant sustainability strategy’ can be found, for instance, in a corporation that has recently integrated sustainability within its balance scorecard but does not mobilize this system due to the emergence of new radical uncertainties-e.g. prospect of a merger or of an hostile takeover-which temporarily prevents the adoption of strategic action.

The existence of the 'dormant sustainability strategy' configuration finds similar rationale in the 'dormant strategy' context minus the fact that control systems are integrated here. However, in this situation, given a lack of strategic vision, the prospects for sustainability strategizing are yet higher than in the 'dormant decoupled strategy' case, because interactive engagement by the top management team with one or both system(s) is sufficient for moving the corporation to configurations leading to a better integration of sustainability.

The parameters of this configuration are thus expected to be similar to the ones of 'dormant coupled strategy', with a low level of stability, a low frequency and a low capacity to create a convergence between the various dimensions of performance.

\subsection{Sustainability driven strategy (Configuration F)}

A second 'high integration' configuration is the case of an organization within which the MCS is not used interactively and where the strategy-making process is driven by sustainability through the interactive use of the sustainability control system. This 'sustainability driven organizational strategy' corresponds, for instance, to the situation of sustainable businesses at their early very stage of development. Organizations at an early 
stage of development may have not yet integrated in their strategy-making process any formalized MCSs. Yet, as these organizations' business models embed sustainability, the need to formalize and control sustainability related data and behaviour may be far higher, leading to an interactive use of this system, and to the development of an integrated MCS as a by-product.

This configuration can be observed in the case of 'green' start-ups addressing sustainability issues through their business model or at the early stages of corporate development focused on social responsibility or sustainability products / services. Medium sized corporations having constructed their business model around sustainability such as Innocent Drinks for instance, maybe also be found having such a configuration with a tight integration of SCS and MCS but a dominant focus on the sustainability parameters of their activities. Because it reflects a transitory stage of sustainable corporation development, this configuration's stability and empirical frequency are both medium. From a triple bottom line perspective, organizations in this situation may perform well from a social and environmental perspective, yet struggle to secure enough financial resources for their development. As a result, their triple bottom line performance can be expected to be only modest.

\subsection{Peripheral Sustainability Integration (Configuration G)}

A third configuration exhibiting a high level of integration of control systems is 'peripheral sustainability integration'. This situation corresponds to the case of an organization within which only the regular MCS is used interactively to deploy the strategy, the management of sustainability being used as a diagnostic tool. 
This configuration seems highly plausible from an empirical viewpoint, especially for organizations that have derived their sustainability systems from pre-existing MCSs-and thus enhanced technical integration—while considering that the main strategic uncertainties are not related to the sustainability area, for instance because of the specifics of their industrial sector. In such a configuration, sustainability data do not feed the process of strategy-making and sustainability-driven innovation is thus very unlikely [171]. However, they may engender some constraints and boundaries related to sustainability thanks to diagnostic monitoring of these issues. This situation corresponds to the approach of sustainability or social responsibility management which dominated the design school of strategy [172] as well as the planning school of strategy [173]. Both schools of thought regarded these responsibilities as external 'constraints' weighing on strategic choices rather than 'business opportunities' on their own for strategy making or competitive advantage construction $[174,175]$.

The stability of this configuration can be linked for example to lasting 'cognitive barriers' preventing members of the top management team from perceiving the strategic uncertainties related to sustainability $[176,177]$, even though SCSs and regular MCSs are perfectly integrated technically and organizationally. Executives may thus fail to give full consideration to this issue in their strategy-making processes [178]. This configuration is also likely to occur when the sustainability control systems is directly derived from a reporting system built to comply with external pressures and expectations. Because compliance remains an important driver of organizations' engagement toward sustainability, we can expect this configuration to be relatively frequent from an empirical viewpoint. From a triple bottom line performance viewpoint, organizations characterized by such a configuration may perform only at a medium level, as social and environmental dimensions of performance 
maybe regarded as relatively low organizational priorities, in contrast with financial dimensions of performance.

\subsection{Integrated sustainability strategy (Configuration $\mathbf{H}$ )}

A last configuration corresponds to an ideal-type of interactive use of both integrated systems. In this context of 'integrated sustainability strategy', sustainability strategy and strategymaking overlap completely, allowing the deployment and renewal of a sustainability strategy through the use of coherently integrated systems. This 'ideal'—if empirically rareconfiguration corresponds to the highest level of sustainability or social responsibility implementation described in prior models of CSR deployments $[179,180,181,182]$. It uncovers the control infrastructure that needs to be in place for embedding sustainability.

Such an 'integrated sustainability strategy’ configuration allows managers to derive process, service and products innovations from sustainability engagement $[183,184]$ and is thus fully coherent with a differentiation positioning [185]. This configuration can be assumed to be stable as sustainability and commercial differentiation strategies may reinforce each other over time. In addition, within this configuration, the interactive use of systems can trigger processes of organizational learning and changes [186] which can enhance organizational performance on multiple dimensions.

These eight configurations constitute a parsimonious set of ideal-types of relationships between strategy-making processes and control systems oriented toward different ends (sustainability vs. management). As shown on Table 2, these configurations present various degrees of stability, empirical verisimilitude and their impact on the organizational capacity to deliver a triple bottom line is variable. 
According to Dot and Glick [187], elaborating a typology that articulates components of prior theories (here, integration and use of control systems) constitutes per se a form of theorybuilding. We build here this typology with the aim of further theorizing the processes whereby organizations can progressively integrate sustainability within their strategy owing to the mobilization of control systems.

\section{Exploring moves and paths across configurations}

So far, we have described organizational configurations of systems integration for sustainability, but done little to explain whether and how organizations move from one configuration to another. We can explore the paths to sustainability integration in strategy by linking configurations together, as suggested by Mintzberg [188] or Miller $[189,190]$. This Part starts this work and theorizes the relationships between various configurations. In so doing, we uncover paths to sustainability strategic integration and highlight the processes of systemic integration (move from a low to a high integration level) vs. dissociation (move from high to low levels of integration) and strategic mobilization (move from a diagnostic to an interactive use of systems) vs. demobilization (move from an interactive to a diagnostic use). We first describe the mechanisms that support the various possible moves on Table 2 and then provide empirical illustrations of their possible sequences.

\subsection{Mechanisms for sustainability integration or marginalization}

\subsubsection{Lateral moves: strategic mobilization vs. demobilization}

Lateral moves on Table 2 are driven by changes in the use of control systems. These changes can take the form of strategic mobilization (moves from left to right), when a control system traditionally used in a diagnostic way is used interactively to deploy a strategy. As highlighted by Simons [191], CEOs can mobilize strategically an MCS in order to reorient the 
strategy, especially when they are newly appointed [192]. In selecting a control system to be used interactively, they refocus managerial attention the dimensions judged crucial to enact the new strategy and build a competitive advantage. Accordingly, the mobilization of a 'dormant’ MCS can revitalize or renew corporate strategy.

The balance of interactive vs. diagnostic uses of SCSs and MCSs reflects the strategic priorities and the willingness to actually enhance and deploy a sustainability strategy that can strengthen a firm's competitive advantage [193]. Mobilizing a SCS in using it interactively rather than diagnostically can push the corporation in the direction of sustainability integration within strategy (on Table 2, this corresponds to following moves: from A to B, from $\mathrm{C}$ to $\mathrm{D}$, from $\mathrm{E}$ to $\mathrm{F}$ or from $\mathrm{G}$ to $\mathrm{H}$ ). Our analysis suggests all these moves can impact positively yet more or less strongly the triple bottom line performance, depending on the current level of systems integration.

However, in contrast with strategic mobilization, our analysis also suggests the possible 'demobilization' of a given control system (e.g., moves from D to B, or from D to C). This can happen deliberately, when a CEO decide to de-emphasise a MCS that does not correspond anymore to the strategy s/he wishes to pursue. Following this logic, a sustainability strategy actively deployed through a SCS to mobilize employees, suppliers and customers around sustainability issues can become managed diagnostically, once the uncertainties surrounding sustainability are perceived as controlled.

\subsubsection{Vertical moves: integration vs. disintegration of control systems}

Vertical moves on Table 2 correspond either to enhancement or diminution in the overall levels of integration that result from changes in intensity of technical, social or cognitive 
modes of integration. In altering the levels of systems coupling through these three dimensions, managers and executives may contribute to the facilitation or prevention of sustainability integration within strategy.

Several factors can contribute to alter the various dimensions of integrations, leading to changes in systems coupling. First, at the technical level, the migration toward a new IT management system can enable the sharing of data from various systems, thus facilitating systems integration. In contrast to this situation, a move toward an Enterprise Resource Planning system that cannot process sustainability data can jeopardize prior efforts to integrate SCSs and MCSs. Second, at the organizational level, career management, job design, and the transformation of functional boundaries may either prevent or facilitate the transversal move of people across departments and, in turn, enhance exchanges of information from teams working with sustainability vs. management control systems. However, organizational changes may also enhance departmental boundaries and thus decreases the organizational integration of SCSs and MCSs. Third and finally, at the cognitive level, arguments related to the business case for sustainability can help in overcoming cognitive barriers to sustainability integration whereas the dominance of the shareholder view can make difficult the integration of sustainability in manager’s cognitions.

The combinations and accumulations of moves over these three levels result in changes in the levels of system integration and create switches from lower to higher coupling (moves from A to $\mathrm{E}$, from $\mathrm{B}$ to $\mathrm{F}, \mathrm{C}$ to $\mathrm{G}$ and $\mathrm{D}$ to $\mathrm{H}$ in Table 2), or alternatively undermine integration (moves from $\mathrm{E}$ to $\mathrm{A}$, from $\mathrm{F}$ to $\mathrm{B}$, from $\mathrm{G}$ to $\mathrm{C}$ and from $\mathrm{H}$ to $\mathrm{D}$ on Table 2).

\subsection{Describing paths across configurations}


The framework can account for the complex processes of - and thus clarify the crucial role of - MCSs and SCSs in the progression of sustainability integration within strategy. Yet, it can also help in identifying threats to integration. We describe here a case of sustainability integration and a case of sustainability marginalization.

\subsubsection{Paths toward sustainability integration}

Figure 1 presents three illustrative paths to sustainability integration that can emerge from a journey across various configurations. In line with Table 2, we have highlighted on Figure 1 the empirical plausibility (from white to dark grey) of the various configurations as well as their degree of stability (dotted vs. plain lines).

\section{INSERT FIGURE 1 ABOUT HERE}

A first possible path refers to a move from a 'dormant integrated strategy' (configuration E) to a 'sustainability driven organizational strategy' (configuration F) and from there to ‘integrated sustainability strategy’ (configuration H). This path corresponds to a two stages process of control system mobilization for the purpose of sustainability strategy deployment in an organization within which the MCS and SCS are already close. At first, the SCS becomes mobilized interactively to stress the importance of sustainability and therefore sustainability strategy emerges as the dominant strategy within this organization. During the second stage, the MCS is also use interactively to support the deployment of an integrated strategy that aims at enhancing the corporations’ triple bottom line. 
Path A appears as a plausible trajectory for energy utility corporations that were used to operating in a formerly highly regulated industry and are now in the front line of issues such as global warming that create numerous business uncertainties on both commercially and technically . Because assessment systems and data for the evaluation of energy consumption are already in-use in these corporations, the SCS and MCS may already be well integrated. In addition, sustainability may emerge within these organizational contexts as a topic calling for the mobilization of dedicated control systems that can support strategic renewal and the subsequent integration of sustainability and strategy.

A second path corresponds to a move from 'dormant decoupled strategy' (configuration A) to ‘compliance-driven sustainability strategy' (configuration C), and from there to 'peripheral sustainability integration’ (configuration G) and finally to 'integrated sustainability strategy’ (configuration $\mathrm{H}$ ) (see path $\mathrm{B}$, dotted line on Figure 1). Following the logic of path $\mathrm{B}$, an organization that lacks a strategy first mobilizes the MCS to renew its strategic objective while keeping the management of sustainability on a diagnostic mode, as an answer to external pressures for compliance (move from A to C). Then, an increased integration of the MCS and SCS, for instance through the reengineering of the IT infrastructure and/or organizational processes, allows for a move toward an integration of sustainability (from $\mathrm{C}$ to G). Finally, the mobilization of the SCS achieves the full integration of sustainability within corporate strategy. According to this path, sustainability strategy is emerging, mainly through the undercover incorporation of the SCS within organizational systems. Our description of the configuration suggests this path is highly plausible as configurations $C$ and $G$ appears highly possible from an empirical viewpoint. 
A third possible account for sustainability integration corresponds to path $\mathrm{C}$ on Figure 1 . This journey toward sustainability starts from 'dormant decoupled strategy' (configuration A) to move through the strategic mobilization of the SCS to 'strategy emergence through sustainability' (configuration B) and from there to 'schizoid sustainability strategy' (configuration D) and ultimately to 'integrated sustainability strategy’ (configuration $\mathrm{H}$ ). The successive mobilization of the un-integrated SCS and MCS (moves from A to B, and from B to D) pushes the organization to the instable context of having two separated strategy-making processes focused on different objectives. Control systems integration may appear as a way to rationalize the situation for both purposes.

\subsubsection{Paths toward sustainability marginalization}

In including the possible moves toward lower levels of integration and the mechanism of demobilization, our framework allows for the depiction of paths that explain the progressive marginalization of sustainability initiatives within an organization. Figure 2 describes two trajectories of this kind, whereby an initially integrated sustainability strategy (configuration $\mathrm{H})$ is progressively sidelined within the organization.

\section{INSERT FIGURE 2 ABOUT HERE}

Path D corresponds to a change in the use of the SCS with a move from an interactive to a diagnostic use (move from $\mathrm{H}$ to $\mathrm{G}$ ) followed by a lowering of the level of integration (move from $\mathrm{G}$ to $\mathrm{C}$ ). Path E refers to the succession of similar moves in the reversed order: a change in management control infrastructure first undermines the integration of the SCS and MCS, pushing the corporation in the 'schizoid sustainability strategy' configuration (D), and then, 
this instable configuration leads to a rationalization that consists in abandoning the interactive use of the SCS, and the organization thus ends in the 'compliance driven sustainability strategy' (configuration C).

The case study proposed by Acquier [194] shows the empirical plausibility of these two paths. In the context of an European energy corporation, Acquier indeed shows a sustainability initiative initially supported by top management and a dedicated SCS (or management models) is progressively sidelined and abandoned, for reasons that reflect, one the one hand, a lack of interactive use of the system by the higher echelons of the management and, on the other hand, the lack of fit between the SCS system and the MCS in-use to deploy the corporate strategy. Small and medium sized corporations that have developed their business model around the concept of sustainability may follow a similar path if they upgrade their MCS in ways that does not allow for the integration of sustainability data.

\section{Discussion and Conclusion}

\section{Contributions}

This paper explores the role of control systems in the integration of sustainability within an organization's strategy. Building on the work of Simons on the use of MCSs and elaborating on the concept of systems' integration, we propose a configurations typology of sustainability integration within strategy through management control. We use this typology to clarify the paths and barriers to sustainability integration, stressing the difficulty of integrating sustainability and regular MCSs due to technical, organizational and cognitive barriers.

In so doing our framework delivers a twofold contribution. First, we clarify the underlying management control conditions that facilitate or prevent an actual integration of sustainability 
within strategy. Prior accounts of sustainability integration do not necessarily take into account the underlying infrastructure that allows making sustainability calculable and thus manageable. We identify which elements should be taken into account to evaluate whether an organization has actually the means to deliver a robust sustainability strategy through our configurations typology. We also highlight how and why integration can be prevented or enabled, respectively, by the use and integration of MCSs.

Second, we contribute to prior literature on management control by extending the works of Simons to the domain of sustainability and by specifying the importance of integration of the two parallel worlds of MCSs and SCSs in the process of strategic renewal.

\section{Operationalization}

From an empirical viewpoint, our framework calls for several developments. First, the configurations of our typology can be approached as benchmarks to assess actual organizations' level of integration in future studies. These configurations can be approached as ideal types, and thus the distance of actual organization from these ideal types could be calculated and assessed due to specific distance metrics [195].

Second, quail-quantitative methodologies such as the Boolean analysis or the Qualitative Comparative Analysis (QCA) developed by Charles Ragin have been shown to be powerful to evaluate the predictive power of configurations on specific organizational or institutional outcomes [196,197]. They could be used to operationalize our typology and evaluate the impact of specific configurations on organizations’ sustainable performance. 
Third, our analysis of the paths to sustainability calls for qualitative empirical studies evaluating systematically the processes whereby organizations switch from one configuration to another. These studies could test whether some paths to sustainability are more likely than others. Fourth and finally, future studies could also investigate and specify the influence of the forms of integration on the capacity of organizations to deliver a triple bottom line.

\section{Managerial Implications}

Finally, our framework has strong managerial implications. First, the combination the use and integration of MCSs allows the specification of boundary conditions for sustainability integration. In uncovering the importance of various forms of system integration, our analysis reveals that the strategic mobilization of a sustainability control system by top managers may not be enough to deploy a sustainability strategy. The regular control system may remain a more structuring force of actors’ behaviour, and sustainability systems can remain peripheral or in parallel. In theorizing the importance of systems use, our framework stresses that integrating sustainability into the control system is a sufficient condition to enhance sustainability strategy. Sustainability may be integrated into an MCS such that it remains dormant and does not inform the strategy. A more effective approach for managers willing to raise sustainability awareness is to integrate sustainability control systems within MCSs by interactive use.

Second, the typology of configurations can be used as a repertoire for building an organizational diagnostic of the degree of sustainability integration. It highlights the importance of integrating sustainability within control systems rather than simply relying on discourse to deliver a triple rather than a single bottom line. 
Third, our analysis reveals that some paths may be easier than others to follow in order to elaborate a sustainability strategy. Hence, we highlight important path dependencies to facilitate the progressive integration of sustainability in organizations. 


\section{References}

[1] Nidumolu, R., Prahalad, C. K., Rangaswami, M. R. 2009. Why sustainability is now the key driver to innovation? Harvard Business Review, 57 (September).

[2] Hart, S. 1995. A natural resource-based view of the firm. Academy of Management Review 20(4), 986-1014.

[3] Shrivastava, P. 1994. CASTRATED environment: GREENING management studies, Organization Studies 15(5), 705-726.

[4] Callon, M. 2009. Civilizing markets: Carbon trading between in vitro and in vivo experiments. Accounting, Organization and Society 34(3-4), 535-548.

[5] MacKenzie, D. 2009. Making things the same: Gas, emission rights and the politics of carbon markets. Accounting, Organization and Society 34(3-4), 440-455.

[6] Adams, C., Whelan, G., 2009. Conceptualising Future Change in Corporate Sustainability Reporting. Accounting, Auditing \& Accountability Journal 22(1), 118-143.

[7] Gray, R.H., 2010. Is accounting for sustainability actually accounting for sustainability...and how would we know? An exploration of narratives of organisations and the planet. Accounting, Organizations and Society 35(1), 47-62.

[8] O’Dwyer, B., Owen, D., 2007. The Reporting and Assurance Dimension. In: Crane, A., Matten, D., Moon, J., Siegel, D.S. (Eds.), The Oxford Handbook of Corporate Social Responsibility, Oxford University Press, New York, Oxford, 384-409.

[9] Elkington, J., 1997. Cannibals with Forks: The Triple Bottom Line of 21st Century Business. Oxford, Oxford University Press.

[10] Newton, T., Harte, G. 1997. Green business: Technicist kitsch? Journal of Management Studies 34(1), 75-98.

[11] Deegan, C., 2002. The legitimising effect of social and environmental disclosures - a theoretical foundation. Accounting, Auditing \& Accountability Journal, 15(3), 282-311.

[12] Banerjee, S. B. 2008. Corporate social responsibility: the good, the bad and the ugly. Critical Sociology, 34(1), 51-79.

[13] Gond, J.-P., Palazzo, G., Basu, K. 2009. Reconsidering instrumental corporate social responsibility through the Mafia metaphor, Business Ethics Quarterly, 19(1), 55-58.

[14] Bebbington, J., 2007. Changing organizational attitudes and culture through sustainability accounting. In: Unerman, J., Bebbington, J., O’Dwyer, B. (Eds.), Sustainability Accounting and Accountability. Routledge, London, 226-242.

[15] Durden, C., 2008. Towards a socially responsible management control system, Accounting, Auditing \& Accountability Journal, 21(5), 671-694.

[16] Hopwood, A. 2009. Accouting and the environment. Accounting Organization and Society, 34(34), 433-439.

[17] Ahrens, T., Chapman, C.S., 2007. Management accounting as practice. Accounting, Organizations \& Society, 32, 1-27.

[18] Hopwood, A. G. 1976. Accounting and Human Behavior. Prentice-Hall: Englewood Cliffs, NJ.

[19] Kober, R., Ng, J., Paul, B. J. 2007. The interrelationship between management control mechanisms and strategy. Management Accounting Research, 18, 425-452.

[20] Langfield-Smith, K. (1997). Management control systems and strategy: a critical review, Accounting, Organizations and Society, 22(2), 207-232.

[21] Henry, J.-F. 2006. Management control systems and strategy: a resource-based perspective. Accounting Organization and Society, 31, 529-558.

[22] Marginson, D. E. W. 2002. Management control systems and their effects on strategy formation at middle-management levels: evidence from a UK organization. Strategic Management Journal, 23, 1019-1031. 
[23] Mundy, J., 2010. Creating dynamic tensions through a balanced use of management control systems. Accounting, Organizations and Society, 35(5), 499-523.

[24] Otley, D. T. 1999. Performance management: A framework for management control system research. Management Accounting Research, 10, 363-382.

[25]Simons, R., 1995a. Levers of Control, How Managers Use Innovative Control Systems to Drive Strategic Renewal. Harvard Business School Press, Boston, MA.

[26] Simons, R. 1994. How new top managers use control systems as levers of strategic renewal. Strategic Management Journal, 15, 169-189.

[27] Simons, R., 2000. Performance Measurement and Control Systems for Implementing Strategy. Prentice-Hall, Englewood Cliffs, NJ.

[28] Simons, R. 2005. Levers of Organization Design: How Managers Use Accountability Systems for Greater Performance and Commitment. Boston: Harvard Business School Press

[29] Gond, J.-P. , Herrbach, O., 2006. Corporate social reporting as a learning tool? A theoretical framework, Journal of Business Ethics 65(4), 359-371.

[30] Henri, J.-F., Journault, M. 2009. Revisiting the link between management control systems and strategy in contingency-based research. Paper of the Annual Conference of the Canadian Aaccounting Academic Association.

[31]Henri, J.-F., Journault, M., 2010. Eco-control: The influence of management control systems on environmental and economic performance. Accounting, Organizations and Society 35, 63-80.

[32] Durden, C., 2008. Towards a socially responsible management control system, Accounting, Auditing \& Accountability Journal, 21(5), 671-694.

[33] Burgelman, R. A. 1991. Intraorganizational ecology of strategy making and organizational adaptation: Theory and field research. Organization Science, 2, 239-262.

[34] Simons, R., 1995. Levers of Control, How Managers Use Innovative Control Systems to Drive Strategic Renewal. Harvard Business School Press, Boston, MA.

[35] Emery, F. E., Trist, E. L., 1969. Socio-Technical Systems, in: F.E. Emery (Ed.), Systems Thinking, Penguin, Harmondsworth, 281-296.

[36] Schaltegger, S., Burritt, R.L., 2005. Corporate sustainability, in: H. Folmer, T. Tietenberg T (Eds.), The International Yearbook of Environmental and Resource Economics 2005/2006, Edward Elgar, Cheltenham, 185-222.

[37] Emery, F. E., Trist, E. L., 1969. Socio-Technical Systems, in: F.E. Emery (Ed.), Systems Thinking, Penguin, Harmondsworth, 281-296.

[38] Ahrens, T., Chapman, C.S., 2007. Management accounting as practice. Accounting, Organizations \& Society, 32, 1-27.

[39] Brown, J. S., Duguid, P. 1991. Organizational learning and communities-of-practice: Toward a unified view of working, learning, and innovating. Organization Science, 2, 40-57.

[40] Hoffman, A., \& Bazerman, M. H. 2007. Changing practices on sustainability: Understanding and overcoming the organizational and psychological barriers to action. In: S. Sharma, M. Starik \& B. Husted (Eds.), Organizations and the Sustainability Mosaic. Edward Elgar Publishing.

[41] Hoffman, A., \& Bazerman, M. H. 2007. Changing practices on sustainability: Understanding and overcoming the organizational and psychological barriers to action. In: S. Sharma, M. Starik \& B. Husted (Eds.), Organizations and the Sustainability Mosaic. Edward Elgar Publishing.

[42] Simons, R., 1991. Strategic orientation and top management attention to control systems'. Strategic Management Journal, 12, 49-62.

[43] Simons, 1994

[44] Simons, R., 1995a. Levers of Control, How Managers Use Innovative Control Systems to Drive Strategic Renewal. Harvard Business School Press, Boston, MA.

[45] Simons, 1995b 
[46] Simons, R., 2000. Performance Measurement and Control Systems for Implementing Strategy. Prentice-Hall, Englewood Cliffs, NJ.

[47] Simons, 2006

[48] p. 90 Weber, M. 1904. Max Weber on the Methodology of the Social Sciences. (E. A. Shills \& H. A. Finch, Eds. \& Trans.). Glencoe, IL: Free Press.

[49] Doty D. H., Glick, W. H., 1994. Typologies as a unique form of theory-building: Toward an improved understanding and modeling. Academy of Management Review, 19(2), 231-251.

[50] Mintzberg, H. T. 1983. Structure in lives: Designing effective organizations. Englewood Cliffs, NJ: Prentice Hall.

[51] Langfield-Smith, K., 1997. Management control systems and strategy: a critical review. Accounting, Organizations and Society, 22(2), 207-232.

[52] Simons, R., 2000. Performance Measurement and Control Systems for Implementing Strategy. Prentice-Hall, Englewood Cliffs, NJ.

[53] Langfield-Smith, K., 1997. Management control systems and strategy: a critical review. Accounting, Organizations and Society, 22(2), 207-232.

[54] Chenhall, R., 2003. Management control systems design within its organizational context: findings from contingency-based research and directions for the future. Accounting, Organizations and Society, 28(2-3), 127-168.

[55] Langfield-Smith, K., 1997. Management control systems and strategy: a critical review. Accounting, Organizations and Society, 22(2), 207-232.

[56] Simons, R., 1991. Strategic orientation and top management attention to control systems'. Strategic Management Journal, 12, 49-62.

[57] Widener, S.K., 2007. An empirical analysis of the levers of control framework. Accounting, Organizations and Society,32, 757-788.

[58] Abernethy, M.A. and Brownell, P., 1999. The role of budgets in organizations facing strategic change: an exploratory study. Accounting, Organizations and Society, 24(3), 189-204.

[59] Bisbe, J. and Otley, D.T., 2004. The effects of the interactive use of management control systems in product innovation. Accounting, Organizations and Society, 29(8), 709-737.

[60] Henri, J-F., 2006. Management control systems and strategy: a resource-based view. Accounting, Organizations and Society, 31, 529-558.

[61] Kober, R., Ng, J. and Paul, B.J., 2007.The interrelationship between management control mechanisms and strategy. Management Accounting Research, 18(4), 425-452.

[62] Simons, R., 1995. Levers of Control, How Managers Use Innovative Control Systems to Drive Strategic Renewal. Harvard Business School Press, Boston, MA.

[63] Simons, R., 1995. Levers of Control, How Managers Use Innovative Control Systems to Drive Strategic Renewal. Harvard Business School Press, Boston, MA.

[64] Simons, R., 2006. Performance Measurement and Control Systems for Implementing Strategy: Text and Cases. Prentice-Hall, Englewood Cliffs, NJ.

[65] Widener, S.K., 2007. An empirical analysis of the levers of control framework. Accounting, Organizations and Society,32, 757-788.

[66] Simons, R., 2000. Performance Measurement and Control Systems for Implementing Strategy. Prentice-Hall, Englewood Cliffs, NJ.

[67] Mundy, J., 2010. Creating dynamic tensions through a balanced use of management control systems. Accounting, Organizations and Society, 35(5), 499-523.

[68] Simons, R., 1990. The role of management control systems in creating competitive advantage: new perspectives. Accounting, Organizations and Society, 15(1/2), 127-143.

[69] Simons, R., 2006. Performance Measurement and Control Systems for Implementing Strategy: Text and Cases. Prentice-Hall, Englewood Cliffs, NJ. 
[70] Merchant, K., 1985. Organizational controls and discretionary program decision making: a field study. Accounting, Organizations and Society, 10(1), 67-85.

[71] Bisbe, J. and Otley, D.T., 2004. The effects of the interactive use of management control systems in product innovation. Accounting, Organizations and Society, 29(8), 709-737.

[72] Nixon, W.A.J. and Burns, J., 2005. Management control in the 21st century. Management Accounting Research, 16(3), 260-268.

[73] Berry, A.J., Coad, A.F., Harris, E.P., Otley, D.T. and Stringer, C., 2009. Emerging themes in management control: a review of recent literature. British Accounting Review, 41(1), 2-20.

[74] Malmi, T. and Brown, D.A. , 2008. Management control systems as a package - opportunities, challenges and research directions. Management Accounting Research, 16, 287-300.

[75] Chenhall, R., 2003. Management control systems design within its organizational context: findings from contingency-based research and directions for the future. Accounting, Organizations and Society, 28(2-3), 127-168.

[76] Fisher, J.G., 1995. Contingency-based research on management control systems: categorization by level of complexity. Journal of Accounting Literature, 14, 24-53.

[77] Fisher, J.G., 1998. Contingency theory, management control systems and firm outcomes: past results and future directions. Behavioural Research in Accounting, 10 (Supplement), 47-57.

[78] Flamholtz, E., Das, E. And Tsui, A., (1985). Toward an integrative framework of organizational control. Accounting, Organizations and Society, 10(1), 35-50.

[79] Langfield-Smith, K., 1997. Management control systems and strategy: a critical review. Accounting, Organizations and Society, 22(2), 207-232.

[80] Otley, D., (1980). The contingency theory of management accounting: achievement and prognosis. Accounting, Organizations and Society, 5, 231-244.

[81] Malmi, T. and Brown, D.A. , 2008. Management control systems as a package - opportunities, challenges and research directions. Management Accounting Research, 16, 287-300.

[82] Malmi, T. and Brown, D.A. , 2008. Management control systems as a package - opportunities, challenges and research directions. Management Accounting Research, 16, 287-300.

[83] Ouchi, W.G., 1977. The relationship between organizational structures and organizational control. Administrative Science Quarterly, 22(1) 95-112.

[84] Simons, R., 2006. Performance Measurement and Control Systems for Implementing Strategy: Text and Cases. Prentice-Hall, Englewood Cliffs, NJ.

[85] Langfield-Smith, K., 1997. Management control systems and strategy: a critical review. Accounting, Organizations and Society, 22(2), 207-232.

[86] Widener, S.K., 2007. An empirical analysis of the levers of control framework. Accounting, Organizations and Society,32, 757-788.

[87] Abernethy, M.A. and Brownell, P., 1999.The role of budgets in organizations facing strategic change: an exploratory study. Accounting, Organizations and Society, 24(3), 189-204..

[88] Bisbe, J. and Otley, D.T., 2004. The effects of the interactive use of management control systems in product innovation. Accounting, Organizations and Society, 29(8), 709-737.

[89] Kober, R.; Ng, J. and Paul, B.J., 2007.The interrelationship between management control mechanisms and strategy. Management Accounting Research, 18(4), 425-452.

[90] Vaivio, J,. 2004. Mobilizing local knowledge with "proactive” non-financial measures. European Accounting Review, 13, 39-71.

[91] Bisbe, J. and Otley, D.T., 2004. The effects of the interactive use of management control systems in product innovation. Accounting, Organizations and Society, 29(8), 709-737.

[92] Henri, J-F., 2006. Management control systems and strategy: a resource-based view. Accounting, Organizations and Society, 31, 529-558. 
[93] Marginson, D.E.W., 2002. Management control systems and their effects on strategy formation at middle-management levels: evidence from a UK organisation. Strategic Management Journal, 23(11), 1019-1031.

[94] Tuomela, T_S., 2005. The interplay of different levers of control: a case study of introducing a new performance measurement system. Management Accounting Research, 16, 293-320.

[95] Bisbe, J. and Otley, D.T., 2004. The effects of the interactive use of management control systems in product innovation. Accounting, Organizations and Society, 29(8), 709-737.

[96] Davila, A., 2000. An empirical study on the drivers of management control systems design in new product development. Accounting, Organizations and Society, 25, 383-410.

[97] Bruining, H., Bonnet, M. and Wright, M., 2004. Management control systems and strategy change in buyouts. Management Accounting Research, 15(2), 155-177.

[98] Widener, S.K., 2007. An empirical analysis of the levers of control framework. Accounting, Organizations and Society,32, 757-788.

[99] Mundy, J., 2010. Creating dynamic tensions through a balanced use of management control systems. Accounting, Organizations and Society, 35(5), 499-523.

[100] Bhimani, A., Langfield-Smith, K., 2007. Structure, formality and the importance of financial and non-financial information in strategy development and implementation. Management Accounting Research, 18(1), 3-31.

[101] Norris, G. \& O’Dwyer, B., 2004. Motivating socially responsive decision making: the operation of management controls in a socially responsive organisation. British Accounting Review 36, 173-196.

[102] Bonacchi, M., Rinaldi, L., 2007. DartBoards and Clovers as New Tools in Sustainability Planning and Control, Business Strategy and the Environment, 16(7), 461-473.

[103] Durden, C., 2008. Towards a socially responsible management control system, Accounting, Auditing \& Accountability Journal, 21(5), 671-694.

[104] Burritt, R.L., Schaltegger, S., 2010. Sustainability accounting and reporting: fad or trend?, Accounting, Auditing \& Accountability Journal, 23(7), 829-846.

[105] Lamberton, G., 2005. Sustainability Accounting- A Brief History and Conceptual. Framework. Accounting Forum 29 (1), 7-23.

[106] Thomson, I., 2007. Mapping the terrain of sustainability accounting. In: Unerman, J., Bebbington, J., O’Dwyer, B. (Eds.), Sustainability Accounting and Accountability. Routledge, London, 19-36.

[107] Schaltegger, S., Burritt, R., 2010. Sustainability Accounting for Companies. Catchphrase or Decision Support for Business Leaders? Journal of World Business, 375-384

[108] Durden, C., 2008. Towards a socially responsible management control system, Accounting, Auditing \& Accountability Journal, 21(5), 671-694.

[109] Gond, J.-P., Herrbach, O., 2006. Corporate social reporting as a learning tool? A theoretical framework. Journal of Business Ethics 65(4), 359-371.

[110] Norris, G. \& O’Dwyer, B., 2004. Motivating socially responsive decision making: the operation of management controls in a socially responsive organisation. British Accounting Review 36, 173-196.

[111] Durden, C., 2008. Towards a socially responsible management control system, Accounting, Auditing \& Accountability Journal, 21(5), 671-694.

[112] Herzig, C., Viere, T., Burritt, R.L., Schaltegger, S., 2006. Understanding and supporting management decision-making. South-East Asian case studies on Environmental Management Accounting. In: Schaltegger, S., Bennett, M., Burritt, R.L. (Eds.) Sustainability Accounting and Reporting. Springer, 491-507.

[113] Burritt, R., 2004. Environmental Management Accounting: Roadblocks in the Way to the Green and Pleasant Land. Business Strategy and the Environment 13, 13-32. 
[114] Bebbington, J., 2006. Accounting for sustainable development performance. Research Executive Summaries Series 2(15).

[115] Parnell, J.A. 2008. Sustainable strategic management: construct, parameters, research directions. International Journal of Sustainable Strategic Management 1(1), 35-45.

[116] Milne, M. J. 1996. On sustainability; the environment and management accounting, Management Accounting Research, 7, 135-161.

[117] Salzmann, O., Ionescu-Somers, A., Steger, U., 2005. The Business Case for Corporate Sustainability: Literature Review and Research Options. European Management Journal, 23(1) 27-36.

[118] Zadek, S. 2004.The path to corporate responsibility. Harvard Business Review 82(12), 125-132.

[119] Emery, F. E., Trist, E. L., 1969. Socio-Technical Systems, in: F.E. Emery (Ed.), Systems Thinking, Penguin, Harmondsworth, 281-296.

[120] Adams, C.A., Frost, G.R., 2008. Integrating sustainability reporting into management practices. Accounting Forum, 32, 288-302.

[121] Burritt, R.L., Schaltegger, S., 2010. Sustainability accounting and reporting: fad or trend?, Accounting, Auditing \& Accountability Journal, 23(7), 829-846.

[122] Ahrens, T., Chapman, C.S., 2007. Management accounting as practice. Accounting, Organizations \& Society, 32, 1-27.

[123] Heidmann, M., Schäffer, U., Strahringer, S. 2008. Exploring the Role of Management Accounting Systems in Strategic Sensemaking. Information Systems Management, 25(3), 244257.

[124] Johnson, G., Langley, A., Melin, L., Whittington, R. (Eds.). 2007. Strategy as Practice: Research Directions and Resources. Cambridge, UK: Cambridge University Press.

[125] Whittington, R., 1996. Strategy as practice. Long Range Planning 29(5), 731-735.

[126] Whittington, R., 2007. Strategy practice and strategy process: Family differences and the sociological eye. Organization Studies 28(10), 1575-1586.

[127] Brown, J. S., Duguid, P. 1991. Organizational learning and communities-of-practice: Toward a unified view of working, learning, and innovating. Organization Science, 2, 40-57.

[128] Ahrens, T., Chapman, C.S., 2007. Management accounting as practice. Accounting, Organizations \& Society, 32, 1-27.

[129] Hoffman, A., \& Bazerman, M. H. 2007. Changing practices on sustainability: Understanding and overcoming the organizational and psychological barriers to action. In: S. Sharma, M. Starik \& B. Husted (Eds.), Organizations and the Sustainability Mosaic. Edward Elgar Publishing.

[130] Hoffman, A., \& Bazerman, M. H. 2007. Changing practices on sustainability: Understanding and overcoming the organizational and psychological barriers to action. In: S. Sharma, M. Starik \& B. Husted (Eds.), Organizations and the Sustainability Mosaic. Edward Elgar Publishing.

[131] Hoffman, A., \& Bazerman, M. H. 2007. Changing practices on sustainability: Understanding and overcoming the organizational and psychological barriers to action. In: S. Sharma, M. Starik \& B. Husted (Eds.), Organizations and the Sustainability Mosaic. Edward Elgar Publishing.

[132] Levine, J. M., Moreland, R. L. 1991. Culture and socialization in work groups. In L. B. Resnick, J. M. Levine, \& S. D. Teasdale (Eds.), Perspectives on socially shared cognition. Washington, D.C.: American Psychological Association, 257-279.

[133] pp. 351-352 in Simons, R. 1987. Accounting control systems and business strategy: An empirical analysis. Accounting, Organizations and Society, 12, 357-374.

[134] Simons, R., 1991. Strategic orientation and top management attention to control systems'. Strategic Management Journal, 12, 49-62. 
[135] p. 60 in Simons, R., 1991. Strategic orientation and top management attention to control systems'. Strategic Management Journal, 12, 49-62.

[136] Meyer, M. W., Zucker, L. G. 1989. Permanently Failing Organizations. Newbury Park, CA: SAGE Publications.

[137] Simons, R., 1991. Strategic orientation and top management attention to control systems'. Strategic Management Journal, 12, 49-62.

[138] Meyer, M. W., Zucker, L. G. 1989. Permanently Failing Organizations. Newbury Park, CA: SAGE Publications.

[139] Simons, R. 1994. How new top managers use control systems as levers of strategic renewal. Strategic Management Journal, 15, 169-189.

[140] Simons, R. 1994. How new top managers use control systems as levers of strategic renewal. Strategic Management Journal, 15, 169-189.

[141] Mintzberg, H. T. and Waters, J. A. 1984. Of strategies, deliberate and emergent. Strategic Management Journal, 6, 257-272.

[142] Burgelman, R. A. 1991. Intraorganizational ecology of strategy making and organizational adaptation: Theory and field research. Organization Science, 2, 239-262.

[143] Simons, R. 1990. The role of management control systems in creating competitive advantage: new perspectives. Accounting, Organizations and Society, 15, 127-143.

[144] Simons, R. 1994. How new top managers use control systems as levers of strategic renewal. Strategic Management Journal, 15, 169-189.

[145] Simons, R., 1991. Strategic orientation and top management attention to control systems'. Strategic Management Journal, 12, 49-62.

[146] Simons, R. 1994. How new top managers use control systems as levers of strategic renewal. Strategic Management Journal, 15, 169-189.

[147] Simons, R., 1995. Levers of Control, How Managers Use Innovative Control Systems to Drive Strategic Renewal. Harvard Business School Press, Boston, MA.

[148] Kolk, A., 2003. Trends in sustainability reporting in the Fortune Global 250. Business strategy and the environment 12(5), 279-291.

[149] O’Dwyer, B., Owen, D., 2007. The Reporting and Assurance Dimension. In: Crane, A., Matten, D., Moon, J., Siegel, D.S. (Eds.), The Oxford Handbook of Corporate Social Responsibility, Oxford University Press, New York, Oxford, 384-409.

[150] Mirvis, P., Googins, B. 2006. Stages of corporate citizenship: a developmental framework. California Management Review, 48(2), 104-26.

[151] Zadek, S. 2004.The path to corporate responsibility. Harvard Business Review 82(12), 125-132.

[152] Maon, F., Lindgreen, A., Swaen, V. 2009. Designing and implementing corporate social responsibility: An integrative framework grounded in theory and practice. Journal of Business Ethics, 87, 71-89.

[153] pp. 128-129 in Zadek, S. 2004.The path to corporate responsibility. Harvard Business Review 82(12), 125-132.

[154] pp. 128-129 in Zadek, S. 2004.The path to corporate responsibility. Harvard Business Review 82(12), 125-132.

[155] Boxenbaum, E., Jonsson, S. 2008. Isomorphism, diffusion and decoupling. In: Greenwood, R., Suddaby, R., Oliver, C. Sahlin-Anderson, K. (Eds.). Handbook of Organizational Institutionalism. Sage, 78-98.

[156] Meyer, J. W., Rowan, B. 1977. Institutionalized organizations: Formal structure as myth and ceremony. American Journal of Sociology, 83, 340-363.

[157] Gond, J.-P. , Herrbach, O., 2006. Corporate social reporting as a learning tool? A theoretical framework, Journal of Business Ethics 65(4), 359-371. 
[158] Maon, F., Lindgreen, A., Swaen, V. 2009. Designing and implementing corporate social responsibility: An integrative framework grounded in theory and practice. Journal of Business Ethics, 87, 71.89.

[159] Banerjee, S. B. 2008. Corporate social responsibility: the good, the bad and the ugly. Critical Sociology, 34(1), 51-79.

[160] Deegan, C., 2002. The legitimising effect of social and environmental disclosures - a theoretical foundation. Accounting, Auditing \& Accountability Journal, 15(3), 282-311.

[161] Kets de Vrie, M. F. R., Miller, R. 1984. The Neurotic Organization: Diagnosing and Changing Counterproductive Styles of Management. San Francisco: Jossey-Bass.

[162] Emery, Y., Giauque, D. 2003. Sens et paradoxes de l'emploi public au XXIème siècle. Lausanne : Presses Polytechniques et Universitaires Romandes.

[163] Watzlawick, 1979. The Language of Change. New York: Basic Books.

[164] Oliver, C. 1992. The antecedents of deinstitutionalization. Organization Studies, 13(4), 563-588.

[165] Elsbach, K. B., Sutton, R. I. 1992. Acquiring organizational legitimacy through illegitimate actions: A marriage of institutional and impression management theories. Academy of Management Journal, 35, 699-738.

[166] Gond, J.-P., Palazzo, G., Basu, K. 2009. Reconsidering instrumental corporate social responsibility through the Mafia metaphor, Business Ethics Quarterly, 19(1), 55-58.

[167] Strike, V., Gao, J., Bansal, P. 2006. Being Good While Being Bad: Social Responsibility and the International Diversification of U.S. Firms. Journal of International Business Studies, 37, 850-862.

[168] Banerjee, S. B. 2008. Corporate social responsibility: the good, the bad and the ugly. Critical Sociology, 34(1), 51-79.

[169] Markowitz, L. 2008. Can strategic investing transform the corporation? Critical Sociology, 34(5): 681-707.

[170] Markowitz, L. 2008. Can strategic investing transform the corporation? Critical Sociology, 34(5): 681-707.

[171] Gond, J.-P. , Herrbach, O., 2006. Corporate social reporting as a learning tool? A theoretical framework, Journal of Business Ethics 65(4), 359-371.

[172] Mintzberg, H. T. 1990. The design school: reconsidering the basic premises of strategic management. Strategic Management Journal, 11, 171-195.

[173] Ansoff, I. H. 1965. Corporate Strategy. McGraw-Hill.

[174] Burke, L., Logsdon, J. M., 1996. How corporate social responsibility pays off. Long Range Planning, 29, 4, 495-50.

[175] Porter, M.E., Kramer, M.R., 2006. Strategy \& Society. The Link Between Competitive Advantage and Corporate Social Responsibility. Harvard Business Review, December, 1-15.

[176] Hoffman, A., \& Bazerman, M. H. 2007. Changing practices on sustainability: Understanding and overcoming the organizational and psychological barriers to action. In: S. Sharma, M. Starik \& B. Husted (Eds.), Organizations and the Sustainability Mosaic. Edward Elgar Publishing.

[177] Swanson, D.L. 1999. Toward an integrative theory of business and society: A research strategy for corporate social performance. Academy of Management Review, 24(3), 506-521.

[178] Simons, R. 1994. How new top managers use control systems as levers of strategic renewal. Strategic Management Journal, 15, 169-189.

[179] Mirvis, P., Googins, B. 2006. Stages of corporate citizenship: a developmental framework. California Management Review, 48(2), 104-26.

[180] Maon, F., Lindgreen, A., Swaen, V. 2009. Designing and implementing corporate social responsibility: An integrative framework grounded in theory and practice. Journal of Business Ethics, 87, 71-89. 
[181] Maon, F., Lindgreen, A., Swaen, V. 2009. Designing and implementing corporate social responsibility: An integrative framework grounded in theory and practice. Journal of Business Ethics, 87, 71-89.

[182] Zadek, S. 2004.The path to corporate responsibility. Harvard Business Review, 82(12), 125132.

[183] McWilliams, A., Siegel, D. S. 2001. Corporate social responsibility: A theory of the firm perspective. Academy of Management Review. 26(1), 117-127.

[184] Porter, M.E., Kramer, M.R., 2006. Strategy \& Society. The Link Between Competitive Advantage and Corporate Social Responsibility. Harvard Business Review, December, 1-15.

[185] Porter, M. E. 1980. Competitive Strategy. New York: Free Press.

[186] Gond, J.-P. , Herrbach, O., 2006. Corporate social reporting as a learning tool? A theoretical framework, Journal of Business Ethics 65(4), 359-371.

[187] Doty D. H., Glick, W. H., 1994. Typologies as a unique form of theory-building: Toward an improved understanding and modeling. Academy of Management Review, 19(2), 231-251.

[188] Mintzberg, H. T. 1979. The structuring of organizations. Englewood Cliffs, NJ: Prentice Hall.

[189] Miller, D. 1990. Organizational configurations: Cohesion, change, and prediction. Human Relations, 43(8), 771-789.

[190] Miller, D. 1996. Configurations revisited. Strategic Management Journal, 17, 505-512.

[191] Simons, R., 1991. Strategic orientation and top management attention to control systems'. Strategic Management Journal, 12, 49-62.

[192] Simons, R., 1995. Levers of Control, How Managers Use Innovative Control Systems to Drive Strategic Renewal. Harvard Business School Press, Boston, MA.

[193] Porter, M.E., Kramer, M.R., 2006. Strategy \& Society. The Link Between Competitive Advantage and Corporate Social Responsibility. Harvard Business Review, December, 1-15.

[194] Acquier, A. 2010. CSR in search of a management model: A case of marginalization of a CSR initiative. In: Smith, C., Bhattacharya, C. B., Vogel, D., Levine, D. (eds) Global Challenges in Responsible Business. Cambridge University Press, 107-132.

[195] Doty D. H., Glick, W. H., 1994. Typologies as a unique form of theory-building: Toward an improved understanding and modeling. Academy of Management Review, 19(2), 231-251.

[196] Fiss, P.C. 2007. A set-theoretic approach to organizational configurations. Academy of Management Review, 32(4), 1180-1198.

[197] Fiss, P.C. 2010. Building better causal theories: A fuzzy set approach to typologies in organization research. Academy of Management Journal, in press 


\section{References for Table 1}

A Bonacchi, M., Rinaldi, L.,2007. DartBoards and Clovers as New Tools in Sustainability Planning and Control. Business Strategy and the Environment 16(7), 461-473.

B Burritt, R.L., Schaltegger, S., 2001. On the Interrelationship between Eco- Efficiency and Operational Budgeting. Environmental Management and Health, 2, 158-174.

C Roth, H.P., 2008. Using Cost Management for Sustainability Efforts. The Journal of Corporate Accounting \& Finance 19, 11-18.

D Figge, F., Hahn, T., 2004. Sustainable Value Added: Measuring Corporate Contributions to Sustainability Beyond Eco-Efficiency. Ecological Economics 48(2), 173-187.

E Dias-Sardinha, I., Reijnders, L., Antunes. P., 2002. From environmental performance evaluation to eco-efficiency and sustainability balanced scorecards. Environmental Quality Management 12(2), 51-64.

F Schaltegger, S. \& Wagner. M. (2006). Integrative management of sustainability performance, measurement and reporting, International Journal of Accounting, Auditing and Performance Evaluation, 3(1), 1-19.

G Figge, F., Hahn, T., Schaltegger, S., Wagner, M., 2002. The Sustainability Balanced Scorecard - linking sustainability management to business strategy. Business Strategy and the Environment 11(5), 269-284.

H Kaplan, R.S., Norton, D.P., 2004. Strategy Maps: Converting Intangible Assets into Tangible Outcomes. Boston, MA: Harvard Business School Press.

I Hubbard, G., 2009. Measuring Organizational Performance: Beyond the Triple Bottom Line. Journal of Business Ethics 18(3), 177-191.

J Kolsch, D., Saling, P., Kicherer, A., Grosse-Sommer, A., Schmidt, I., 2008. How to measure social impacts? A socio-eco-efficiency analysis by the SEEBALANCE method. International Journal of Sustainable Development 11(1), 1-23

K Schmidt, I., Meurer, M., Saling, P., Kicherer, A., Reuter, W., Gensch, C.-O., 2004. SEEbalance. Managing Sustainability of Products and Processes with the Socio-EcoEfficiency-Analysis by BASF. Greener Management International 45(Spring), 79-94.

L Dutta, S., Lawson, R.A., 2009. Aligning performance evaluation and reward systems with corporate sustainability goals. Cost Management 23(6), 15-23. 
Table 1. Management Control Systems used by Top Managers and Corresponding Sustainability Control Systems

Management Control Systems Description of the Management Control Systems

1. Strategic planning

2. Budgeting

3. Financial measurement systems

4. Non-financial measurement systems

5. Hybrid measurement systems

6. Project management

7. Evaluation and reward
Alternatively referred to as long-range planning. Based upon forecasts of competitive environments and generally covering a five to ten year time period.

A plan specifying goals to be achieved in the next year and used to monitor subsequent activity. Budgeting incorporates initial preparation and ongoing revisions and updates.

Narrower than information contained in the budget. Includes information such as Return on Investment (RoI) and Economic Added Value (EVA).

Quantity measurements not expressed in financial terms and descriptors of performance. Examples of the former encompass relative positioning in the market and number of new products/services introduced to customers.

A set of financial and non-financial indicators that aim to assess the extent to which strategic objectives are being achieved. Examples include the balanced scorecard and tableaux-de-bord that presents performance measures in chart form.

Used to review discrete blocks of organizational activity and intended to ensure delivery to time and budget. Focus may be on improving project attributes or processes of delivery to customers.

Aim is to direct the efforts of individuals and groups within an organization. Includes determination of criteria for bonus payments.
Sustainability Control Systems deriving

from the Accounting Control Systems

Sustainability planning [A]

Environmental budgeting [B]; Sustainability budgeting [C]

Sustainability performance measurement, Environmental cost accounting systems, Sustainable value added [D]

Environmental performance evaluation systems [E], Material and energy flow accounting systems, Sustainability performance measurement

Sustainability balanced scorecard [F,G,H,I ]

Socio-eco-efficiency analysis [J,K], Environmental investment appraisal

Reward system based on multidimensional performance system [L] 
Table 2. Configuring Uses and Integration of Control Systems

\begin{tabular}{|c|c|c|c|c|c|}
\hline & & \multicolumn{4}{|c|}{ USES OF CONTROL SYSTEMS (DIAGNOSTIC VS. INTERACTIVE) } \\
\hline & & \multicolumn{2}{|c|}{ DiAgNOSTIC USE OF MCS } & \multicolumn{2}{|c|}{ INTERACTIVE USE OF MCS } \\
\hline & & $\begin{array}{c}\text { DIAGNOSTIC USE OF } \\
\text { SCS }\end{array}$ & $\begin{array}{c}\text { INTERACTIVE USE OF } \\
\text { SCS }\end{array}$ & $\begin{array}{c}\text { DIAGNOSTIC USE OF } \\
\text { SCS }\end{array}$ & $\begin{array}{l}\text { INTERACTIVE USE OF } \\
\text { SCS }\end{array}$ \\
\hline $\begin{array}{l}\text { LEVEL OF } \\
\text { CONTROL } \\
\text { SYSTEMS }\end{array}$ & $\begin{array}{c}\text { Low } \\
\text { DECOUPLING }\end{array}$ & $\begin{array}{l}\text { Configuration A } \\
\text { Dormant } \\
\text { decoupled } \\
\text { strategy } \\
\text { Stability: Low } \\
\text { Frequency: Low } \\
\text { TBL: Low }\end{array}$ & $\begin{array}{c}\text { Configuration B } \\
\text { Strategy emergence } \\
\text { through } \\
\text { sustainability } \\
\text { Stability: Medium } \\
\text { Frequency: Low } \\
\text { TBL: Medium }\end{array}$ & $\begin{array}{c}\text { Configuration C } \\
\text { Compliance-driven } \\
\text { sustainability } \\
\text { strategy } \\
\text { Stability: High } \\
\text { Frequency: High } \\
\text { TBL: Medium }\end{array}$ & $\begin{array}{l}\text { Configuration D } \\
\text { Schizoid } \\
\text { sustainability } \\
\text { strategy } \\
\text { Stability: Low } \\
\text { Frequency: Medium } \\
\text { TBL: High (short term) }\end{array}$ \\
\hline $\begin{array}{l}\text { (COGNITIVE, } \\
\text { ORGANIZATIONAL, } \\
\text { TECHNICAL) }\end{array}$ & $\begin{array}{c}\text { HIGH } \\
\text { TIGHT } \\
\text { COUPLING }\end{array}$ & $\begin{array}{l}\text { Configuration E } \\
\text { Dormant } \\
\text { integrated } \\
\text { strategy } \\
\text { Stability: Low } \\
\text { Frequency: Low } \\
\text { TBL: Low }\end{array}$ & $\begin{array}{c}\text { Configuration F } \\
\text { Sustainability-driven } \\
\text { organizational } \\
\text { Strategy } \\
\text { Stability: Low } \\
\text { Frequency: Medium } \\
\text { TBL: Medium }\end{array}$ & $\begin{array}{l}\text { Configuration G } \\
\text { Peripheral } \\
\text { sustainability } \\
\text { integration } \\
\text { Stability: High } \\
\text { Frequency: Medium } \\
\text { TBL: Medium }\end{array}$ & $\begin{array}{l}\text { Configuration H } \\
\text { Integrated } \\
\text { sustainability } \\
\text { strategy } \\
\text { Stability: High } \\
\text { Frequency: Low } \\
\text { TBL: High (long term) }\end{array}$ \\
\hline
\end{tabular}


Figure 1. Exploring Paths to Sustainability Integration

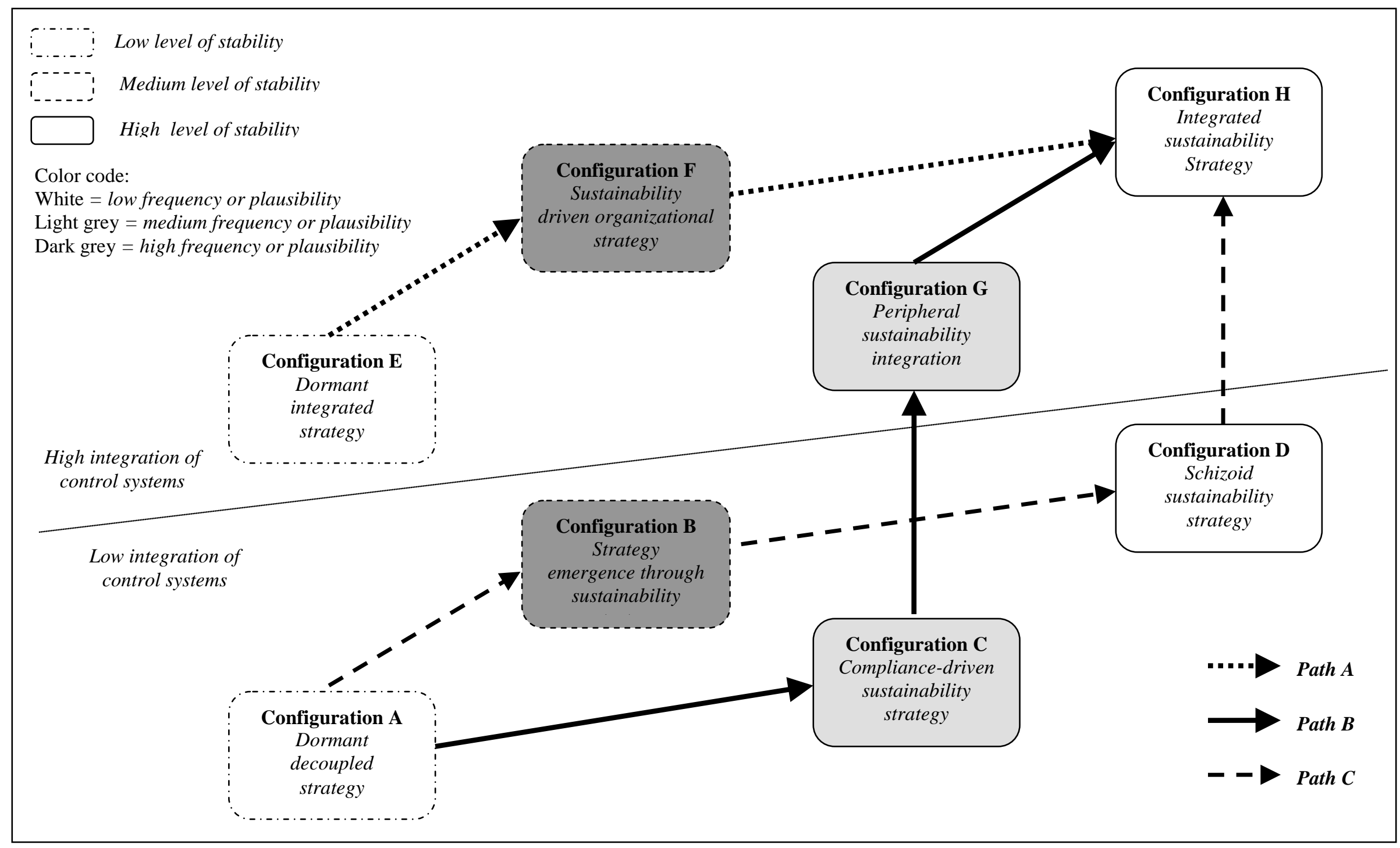


Figure 2. Explaining Sustainability Marginalization

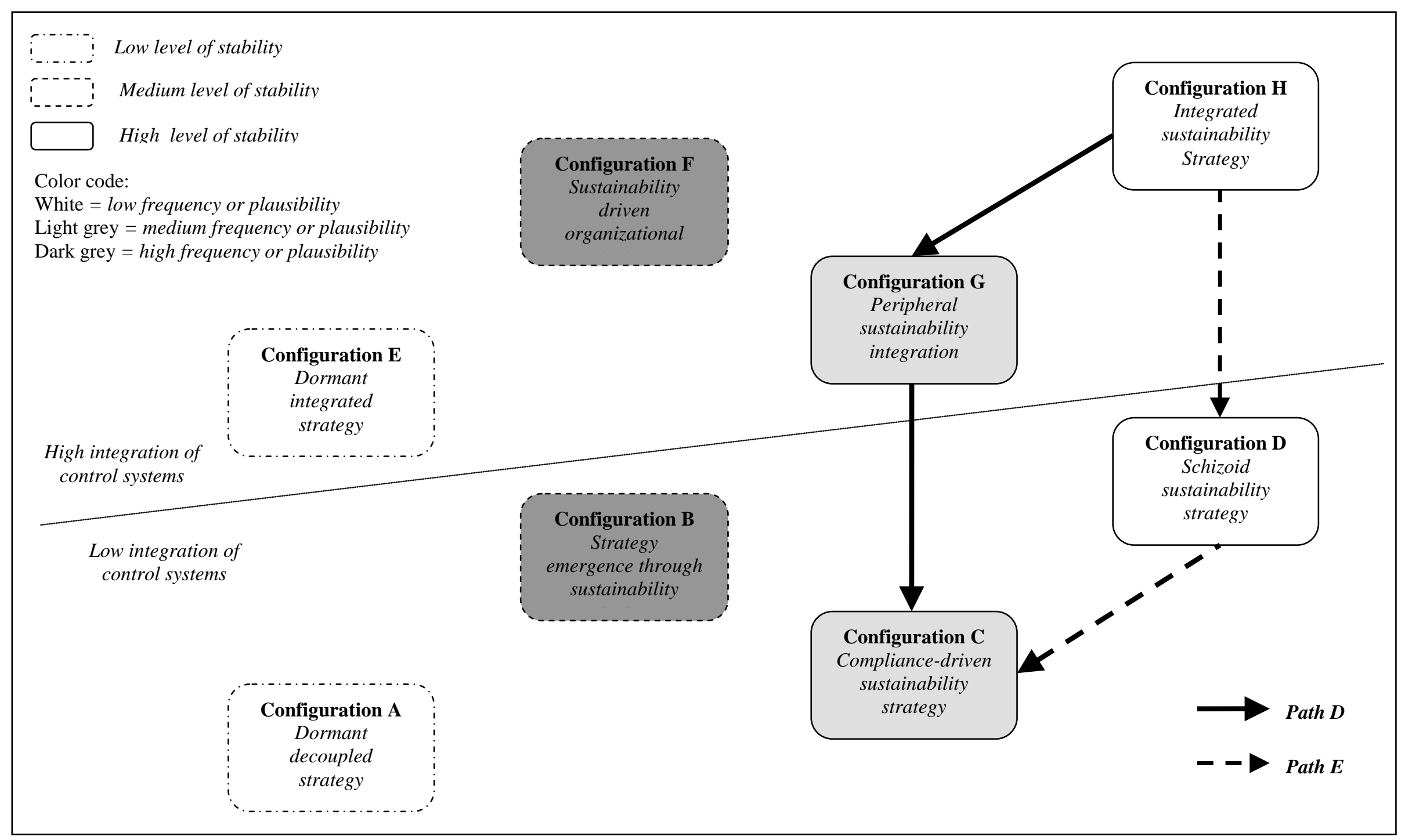

